\title{
Pedogenic and subaerial exposure microfabrics in a late Carboniferous-early Permian carbonate-volcanic lacustrine-palustrine system (San Ignacio Formation, Frontal Cordillera, Argentina)
}

\author{
Isabel Méndez-Bedia ${ }^{1}$, Gloria Gallastegui ${ }^{2}$, Pedro Busquets ${ }^{3}$, Silvia N. Césari ${ }^{4}$, \\ Carlos O. Limarino ${ }^{5}$, Eva Prats ${ }^{6}$, Raúl Cardó 7 , *Ferran Colombo
}

\author{
${ }^{1}$ Departamento de Geología, Universidad de Oviedo, Jesús Arias de Velasco s/n, E-33005 Oviedo, Spain. \\ imbedia@movistar.es \\ 2 Instituto Geológico y Minero de España (IGME), Matemático Pedrayes 25, E-33005 Oviedo, Spain. \\ g.gallastegui@igme.es \\ 3 Departament de Dinàmica de la Terra i de l'Oceà, Universitat de Barcelona, Martí i Franqués s/n, E-08028 Barcelona, Spain. \\ pere.busquets@ub.edu; colombo@ub.edu \\ 4 Museo de Ciencias Naturales Bernardino Rivadavia, Avenida Ángel Gallardo 470, 1405 Buenos Aires, Argentina. \\ scesari@macn.gov.ar \\ 5 Departamento de Ciencias Geológicas, Universidad de Buenos Aires, C1428EHA, Buenos Aires, Argentina. \\ limar@gl.fcen.uba.ar \\ ${ }^{6}$ Centres Científics i Tecnologics (CCiTUB), Universitat de Barcelona, E-08028 Barcelona, Spain. \\ evaprats@ccit.ub.edu \\ Servicio Geológico y Minero Argentino (SEGEMAR), Sargento Cabral 685, 5400 Oeste, San Juan, Argentina. \\ rcardo@segemar-sanjuan.com.ar \\ * Corresponding author: colombo@ub.edu
}

\begin{abstract}
In the Argentinian Andes (Frontal Cordillera) the upper part of the late Carboniferous-early Permian San Ignacio Formation is made up of lacustrine-palustrine microbial carbonates and interbedded volcanic deposits. In this lacustrine-palustrine environment a natural monospecific forest was developed. The deposits of this sedimentaryvolcanic succession were repeatedly subjected to subaerial exposure and modified by pedogenesis to varying degrees giving rise to paleosoils development. Diagenetic microfabrics were well preserved in the carbonates and volcanic rocks. The carbonate microfabrics comprise a wide spectrum of features consisting of root marks and stumps-related structures (rhizoliths, alveolar texture, tunnel-like structures and coprolites of arthropods), pisoids, coated grains and pseudomicrokarst, cracking, brecciated and nodular fabrics, and grainification also occur corresponding to different stages in the pedogenic evolution. Meteoric dissolution and cementation processes are observed; examples are well identified by scanning electron microscope showing silica-filled voids in partially dissolved carbonates and growths of inorganic carbonate microcrystals or of microbial origin in voids. Other different types of cements can be seen such as discontinuous carbonate crusts, ribbon spar, cavities with silt infillings and pendant cements. The whole set of these microfabrics are indicative of wetting, desiccation and meteoric conditions (vadose and phreatic). The abundance of plant roots and associated micro-organisms mainly of bacterial origin (micro-rods, short rod-shapes, nano-fibres, filaments and nano-spheres) played an important role in the pedogenic and subaerial diagenetic processes affecting these deposits. The immature character of the paleosoils and absence of calcretes point out to short intervals of subaerial exposure due to oscillating fluctuations in water level, intermittent volcanic supply, tectonic subsidence and oscillating climatic conditions. The whole of the macro and microfabrics reveals that the prevailing weather could correspond to an intermediate between semi-arid to sub-humid, however the alternating wetting and drying conditions in which the fossil forest developed and the abundance and diversity of micro-organisms, suggest a transition to sub-humid climate conditions.
\end{abstract}


RESUMEN. Microfábricas pedogénicas y de exposición subaérea en el sistema volcánico y lacustre de la Formación San Ignacio (Carbonífero superior-Pérmico inferior), Cordillera Frontal, Argentina. En los Andes argentinos (Cordillera Frontal), la parte superior de la Formación San Ignacio (Carbonífero superior-Pérmico inferior) está constituida por carbonatos microbiales de origen lacustre-palustre interestratificados con depósitos volcánicos. En ese ambiente sedimentario lacustre-palustre se desarrolló un bosque natural monoespecífico. Los depósitos carbonáticos y volcánicos de esa sucesión fueron afectados por repetidas exposiciones a condiciones subaéreas y modificados por pedogénesis en diferentes grados. Las microfábricas diagenéticas quedaron bien preservadas en los carbonatos y en las rocas volcánicas. Las microfábricas carbonáticas muestran un amplio espectro de características correspondientes a estructuras de raíces y troncos (rizolitos, texturas alveolares, estructuras tuneliformes y coprolitos de artrópodos), pisolitos, granos con recubrimientos, pseudomicrokarst, fracturación, fábricas brechoides y nodulares así como granificación correspondiente a diversos estadios de evolución pedogénica. Además, se observan diferentes procesos de disolución y cementación meteórica de los depósitos de carbonato. Diversos ejemplos, estudiados mediante microscopio electrónico, muestran rellenos silíceos de cavidades existentes en carbonatos parcialmente disueltos y crecimientos de cristales de calcita de origen inorgánico y microbial. Asimismo, se han identificado otros tipos de cementos como costras carbonáticas, esparita cordoniforme, cavidades con rellenos limosos y cementos colgantes. El conjunto de esas microfábricas indica humectación, desecación y condiciones meteóricas (vadosas y freáticas). La abundancia de raíces de plantas y de microorganismos asociados, principalmente de origen bacteriano (microvarillas, microfibras, filamentos y nanoesferas), han jugado un papel importante en los procesos pedogénicos y diagenéticos que afectaron a estos depósitos. El carácter inmaduro de los paleosuelos y la ausencia de calcreta indica que los periodos de exposición fueron cortos, debido a fluctuaciones del nivel del agua, actividad volcánica intermitente, subsidencia tectónica y unas condiciones climáticas variables. El conjunto de macro y microestructuras indica la prevalencia de un clima intermedio entre semiárido y semihúmedo, aunque las condiciones alternantes de sequedad y humedad en las que se desarrolló el bosque fósil y la abundancia y diversidad de microorganismos sugieren una transición a condiciones climáticas semihúmedas.

Palabras clave: Carbonatos palustres en un contexto volcánico, Microfábricas de exposición subaérea, Características pedogénicas, Paleozoico superior, Cordillera Frontal, Argentina.

\section{Introduction}

Subaerial exposure features in carbonate and, to a lesser extent, volcanic rocks are present in the late Carboniferous-early Permian of the Argentinian Andes (Frontal Cordillera), namely in the San Ignacio Formation.

The upper part of the San Ignacio Formation (105 $\mathrm{m}$ thick) is formed by microbial carbonate and volcanic deposits alternations and represents deposition in a lacustrine-palustrine setting characterized by very low gradients of the lake margin (Busquets et $a l ., 2013 \mathrm{a}, \mathrm{b})$. In this environment an exceptionally well-preserved fossil forest was found; trees in this forest were rooted in a volcanic weathered substrate and carbonate muds (Césari et al., 2010, 2012). These deposits were exposed to periods of subaerial conditions and consequently they were modified with different intensity by pedogenesis and meteoric diagenesis (both vadose and phreatic). The repeated wetting and drying of the carbonate muds caused cracking, dissolution, enlargement of voids, reprecipitation of carbonates and different types of cements related to subaqueous deposition and subaerial exposure. All these processes modified, at different rates, the original fine-grained carbonates, giving rise to a variety of palustrine facies and microfabrics as reviewed in previous years by Freytet and Verrecchia (2002), Alonso-Zarza (2003), and Alonso-Zarza and Wright (2010a).

The main aim of this contribution is to identify, illustrate, and interpret mainly the carbonate microfabrics supporting subaerial exposure. Furthermore, the analysis of these microfabrics and their different types allow us to determine the degree and evolution of pedogenic modification in the upper part of the San Ignacio Formation. The presence of these microfabrics may be very useful in order to recognize the existence of subaerial exposure, and therefore pedogenic processes and paleosoils, when there is hardly any evidence seen in the outcrops. Moreover, it is important to take into account the difficulty to recognize these processes in old deposits, as studied herein, due to the poor preservation related to age. In this sense, in the upper part of the San Ignacio Formation, except the presence of the fossil forest developed at a single level of this stratigraphic sequence, plant root-related structures, and some local desiccation cracks, subaerially generated features are difficult 
to identify on a macroscopic scale. Another aim of this contribution is the analysis of several kinds of cements observed in the rocks of the upper part of this formation whose interpretation is indicative of different types of meteoric diagenesis.

The observed pedogenic microfabrics on the top of the alternating carbonate and volcanic deposits through this succession confirm the statement referred to the medium to high exposure index by Busquets et al. (2013b). Furthermore, the pedogenic microfeatures recorded in these rocks can be significant for evaluating the prevailing paleoclimatic conditions during the subaerial exposure intervals. Thus, this work increases the present knowledge of the sedimentary and paleoenvironmental framework of the upper part of the San Ignacio Formation.

\section{Geological setting}

A very well-exposed stratigraphic succession of the San Ignacio Formation (Rodríguez-Fernández et al., 1996, 1997) crops out extensively in the Frontal Cordillera (Groeber, 1938) of the Argentinean Andes (Fig. 1A, B). According to stratigraphic and palynological data, this unit is considered to be of late Carboniferous-early Permian age (Busquets et al., 2007a, b). The base of the San Ignacio Formation lies unconformably over the Cerro Agua Negra Formation (Fig. 2), constituting an irregular paleotopography. Strikingly the top is another unconformity with regional significance that forms the base of the Choiyoi Group. This unconformity produced a high relief surface causing the erosion of the whole of the San Ignacio Formation in several localities of the Andean Cordillera (Heredia et al., 2002; Busquets et al., 2005). Thus, in many places the Cerro Agua Negra Formation (PennsylvanianCisuralian?) constitutes the basement of the Choiyoi Group (Cisuralian to the earliest Triassic), which was produced by the most extensive volcanic activity along the western margin of Gondwana, where volcanic materials exceeding $5,000 \mathrm{~m}$ in thickness accumulated (Llambías, 1999). The San Ignacio Formation (Fig. 1A, B) was deposited in a retroarc foreland basin related to the Gondwanan thrust (Heredia et al., 2002) and it is a piggy-back basin evidenced by growth strata, and slumps of different magnitude (Busquets et al., 2008). This formation is at least $185 \mathrm{~m}$ thick at the Nipas section (Fig. 1B), although the thickness is variable due to that the lower part fills a paleo-relief and in the upper part locally synsedimentary tectonic thickenings occur linked to an erosive surface (Busquets et al., 2008). The succession consists of a lower part, about $80 \mathrm{~m}$ thick, made up of conglomerates, breccias, sandstones, and some interbedded volcanic rocks, deposited in alluvial-fluvial systems, and an upper part of $105 \mathrm{~m}$ thick constituted by limestones (mostly of microbial origin), volcanic rocks, and minor shales and sandstones (Fig. 2).

According to Busquets et al. (2013b) carbonate and volcanic deposits are organized in sequences that occur repeatedly (Fig. 3A). The first carbonate occurrence, about 70-80 $\mathrm{m}$ from the base of the succession, corresponds to very thin layers of limestone, which get progressively thicker until they become the main components of the succession (Fig. 2). Many of the carbonate rocks are microbialites (as defined by Burne and Moore, 1987), arranged in shallowing-upwards sequences ( 0.1 to $9 \mathrm{~m}$ thick), generally incomplete, consisting from bottom to top of: thrombolites forming domes, stromatolites and paleosoils with different degrees of development. In one of this paleosoils a fossil forest with abundant silicified trunks (Fig. 3B), in some cases with tree stumps in life position, is very well preserved (Césari et al., 2010, 2012). The limestones exhibit signs of extensive diagenetic processes with abundant silicification and, to a lesser degree, dolomitization. Evidence of synsedimentary instability such as slumps and breakages of carbonate beds is also present. Commonly, the carbonate sequences rest on volcanic rocks, and also are sharply overlain by volcanic deposits consisting of pyroclastic rocks related to explosive eruptions, ignimbrites and ash-fall tuffs, epiclastic deposits of volcanic conglomerates, breccias and sandstones, and less frequent lava flows (Busquets et al., 2013b). The volcanism, hydrothermal fluids, abundance of organic nutrients provided by decaying flooded plants, as well as slow water circulation and water features, favoured the growth of microbes, microbial carbonate precipitation and silica permineralization of tree trunks and other plant remains (Busquets et al., 2013b; Césari et al., 2010, 2012).

These sequences have been deposited in a shallow lacustrine-palustrine system subject to fluctuations in water level giving rise to repeated events of flooding and desiccation. Fluctuations in water level are related to contemporary volcanic supply, tectonic subsidence and microbial growth, without ruling 


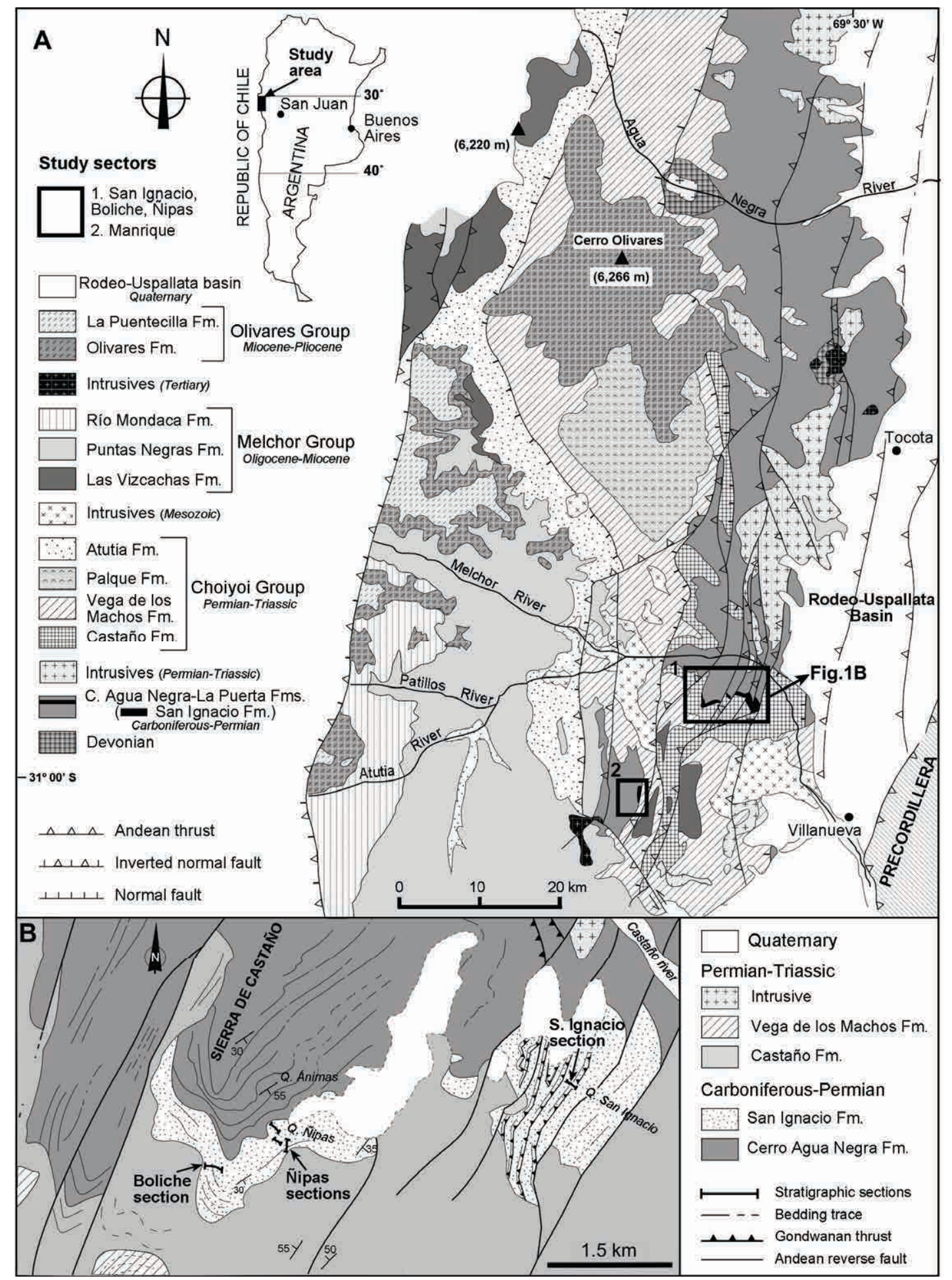

FIG. 1. A. Geological map showing the main geological units and the location of the study sectors: 1. Quebradas de San Ignacio, Ñipas (Ñipas-El Boliche), 2. Quebrada de Manrique. B. Geological map of the San Ignacio Formation with the location of the stratigraphic sections performed in sector 1 (After Heredia et al., 2002, modified). 

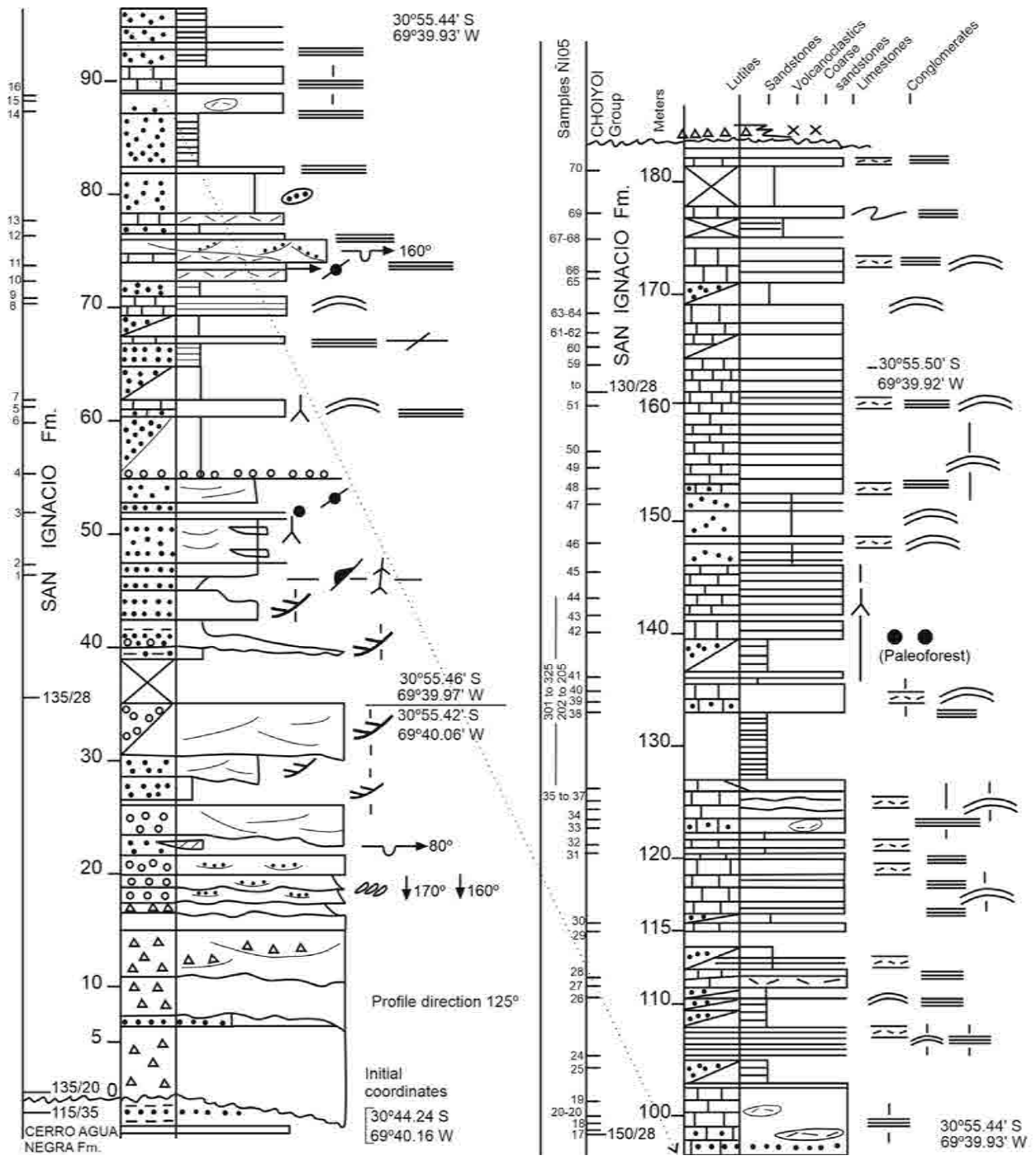

Limestones

Breccias clast supported

$\because \ldots: \%$ Conglomerates clast supported

id: Sandstones

Siltstones

-Z=- Lutites

Volcaniclastic with

r...... carbonate

Dos Imbricate clasts

g.0 Paleocurrent

2 Sand bar

$\longrightarrow$ Scour

$\checkmark$ Cross lamination

(1) Intraformational clasts

2 Slump

$\bar{\equiv}$ Stromatolite

$\Longrightarrow$ Dome-shaped stromatolite

$\angle \quad$ Broken stromatolite lamina

I八 Thrombolite

135/20 Dip and strike

m Angular unconformity boundary

$\sim$ Erosive bottom

Cross-stratification

o. Sandstones

$\bowtie$ Under cover

1 Half under cover

入 Vascular plants in life position

入 Paleosoils

- Silicified tree stumps

- Abundant silicified tree stumps

(paleoforest)

Carbonized plant remains Stump tree remains

FIG. 2. Stratigraphic section of the San Ignacio Formation. Detailed distribution of the studied samples is also shown. 

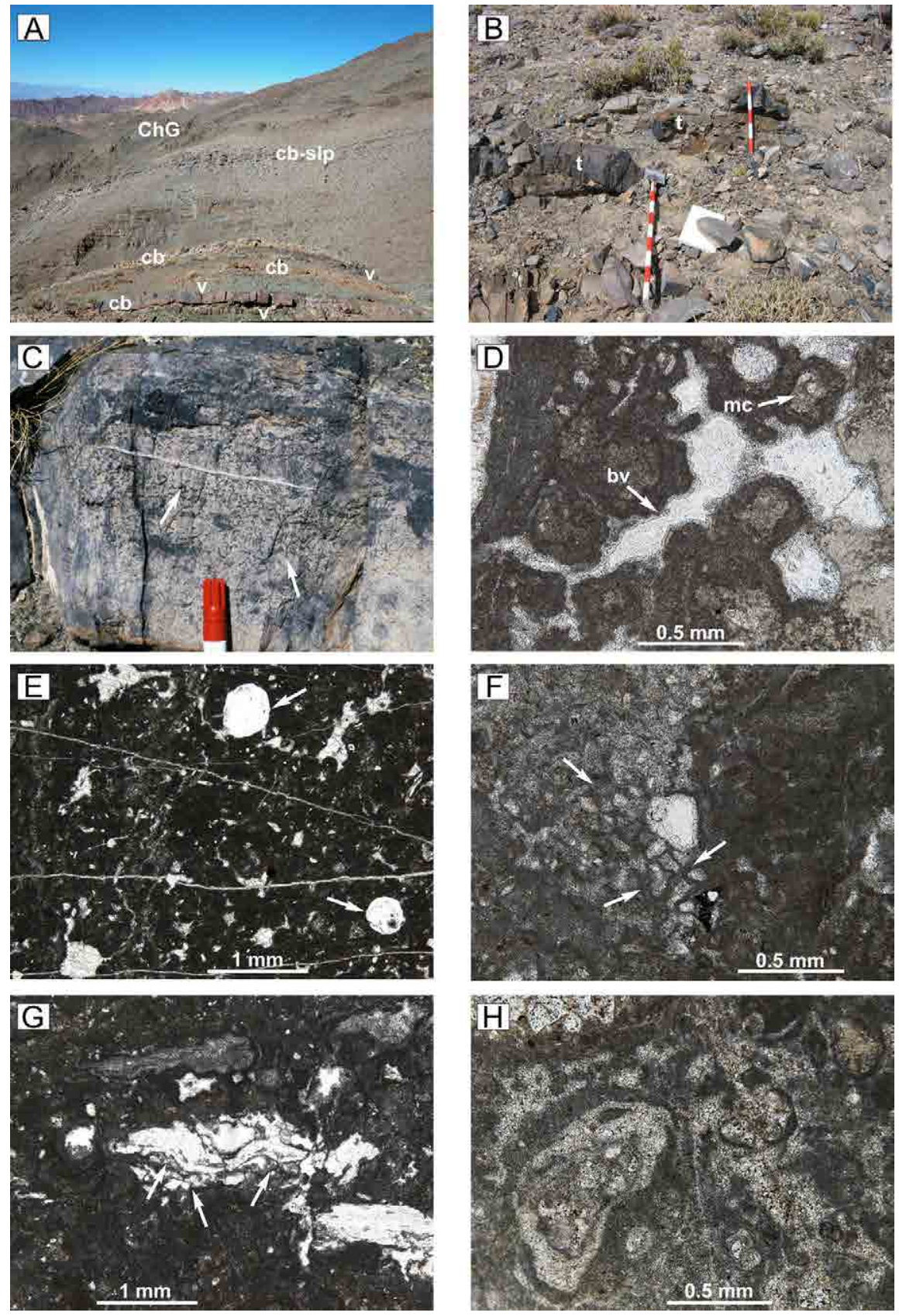

FIG. 3. A. General view of the upper part of the San Ignacio Formation consisting of alternating carbonates (cb) and volcanic (v) deposits. Slumps within some carbonate layers (cb-slp), close to the unconformable boundary with the volcanic rocks of the Choiyoi Group (ChG), can be seen. B. Fossilized tree trunks (t) in horizontal position, parallel to the stratification of the San Ignacio Formation sedimentary rocks. C. Close up view of paleosoil carbonate facies displaying root tubule structures (rhizoliths), white arrows. D. Spar-filled branching voids (bv) due to decayed plant roots. Grains with micritic coatings (mc) are also observed. E. Root casts shown in transverse sections as circular voids filled by sparite (white arrows) and with a clotted micritic coating. F. A close up view of alveolar texture seen as a network of voids of irregular shape (white arrows). G. A complex alveolar texture of elongated to irregular pores defined by very thin micritic walls (white arrows). Above this structure probable alga remains are observed and some voids filled with vadose sediment. H. Alveolar septal texture showing a diffuse coarsening of the calcite crystal towards the centre of the pores. This sample is partially dolomitized. D-H photomicrographs in plane-polarized light. 
out the effects of an oscillating climate (Busquets et al., 2013b and references therein); climate or water level fluctuations are also indicated by the growth under recurrent wetter and drier conditions of the fossil forest (Césari et al., 2010, 2012). The thrombolites were formed in relatively deeper conditions of the lake and the stromatolites grew on them in shallower water areas. During periods of lake contraction, this shallowing- upwards process led to extensive subaerial exposure, soils formation, and locally reworked by tractive water currents. Some cross-bedding calcareous sandstones caused by turbulent water currents (bedforms), made up of grains and clasts of microbialites, occur interbedded with these facies.

\section{Material and methods}

The studied material comes from a previous work focused on a thorough facies and a multidisciplinary analysis of carbonates deposits, volcanic rocks and plant remains that led to a depositional model of the upper part of the San Ignacio Formation (Busquets et $a l ., 2013 b)$. Samples of the pedogenically modified deposits were collected from stratigraphic sections at the Quebradas de Ñipas (Ñipas-El Boliche), San Ignacio (sector 1, Fig. 1A, B) and Manrique (sector 2, Fig. 1A). In this work thin sections of carbonates, permineralized tree remains and volcanic rocks, as well as polished thin sections of the permineralized tree remains were studied in the laboratory; a part of the thin sections were stained with alizarin red-S solution.

Additionally, scanning electron microscopy (SEM) analysis was used in order to gain a better understanding of the microstructures related to diagenetic, pedogenic and fluid circulation processes affecting to the carbonate and volcanic deposits. Each sample was prepared from a fresh limestone and volcanic fragment fractured, and mounted on the microscope holder with the aid of silicone. After that, the sample was coated with a thin film of carbon to improve its electrical conductivity. The work has been carried out at the Centres Científics i Tecnològics (CCiTUB) of Barcelona University (Spain) in a conventional scanning electron microscope [Quanta 200 (FEI Co.)] under high vacuum conditions. This microscope is coupled with backscattered electron (BSED) and X-ray energy dispersive (EDS) detectors. The EDS detector allows us to identify the elements that make up the sample from boron to uranium. Two field emission scanning electron microscopes (FESEM) Hitachi S-4100 and Jeol JSM-7100F have also been used.

This analysis has revealed microstructures that provide valuable information supporting the macro scale evidences of subaerial exposure. The position of the samples and the main macrostructures through the upper part of the San Ignacio Formation are indicated in a stratigraphic section (Fig. 2); the microstructures are listed in table 1.

\section{Results}

The pedogenically modified carbonates and volcanic deposits of the upper part of the San Ignacio Formation herein analyzed show a wide spectrum of subaerial exposure-related microfabric features. Some of these microstructures are quite commonly connected to each other. The most relevant features, especially on a microscopic scale, are briefly described and figured below.

\subsection{Remarks on subaerial and biogenic microstructures}

\subsubsection{Roots and stumps-related features}

Structures related to root activity are the most common features observed in the upper part of the San Ignacio Formation and they are also well described in palustrine and pedogenic facies of different ages. They encompass structures named rhizoliths (Dunagan and Driese, 1999) or root traces (Bain and Foos, 1993; Eggleston, 1994, amongst others). In the field, pedogenic carbonate deposits bearing root tubule structures (rhizoliths) are locally observed (Fig. 3C); these are very similar to those figured by Goldstein (1988), Bain and Foos (1993), Eggleston (1994), and Dunagan and Driese (1999). Microscopically, these structures are mostly longitudinal voids filled by spar, wider at the top and branching downwards (Fig. 3D). Not as common, root casts shown in transverse to oblique sections occur; they consist of round (Fig. 3E) or elongated pores empty or filled with calcite cement and with micritic coatings comparable with those illustrated by Eggleston (1994), and Dickson and Saller (1995) in Carboniferous and Permian limestones. Similar root-related structures are also observed in the volcanic deposits, as it will be shown further on (Section 5). 


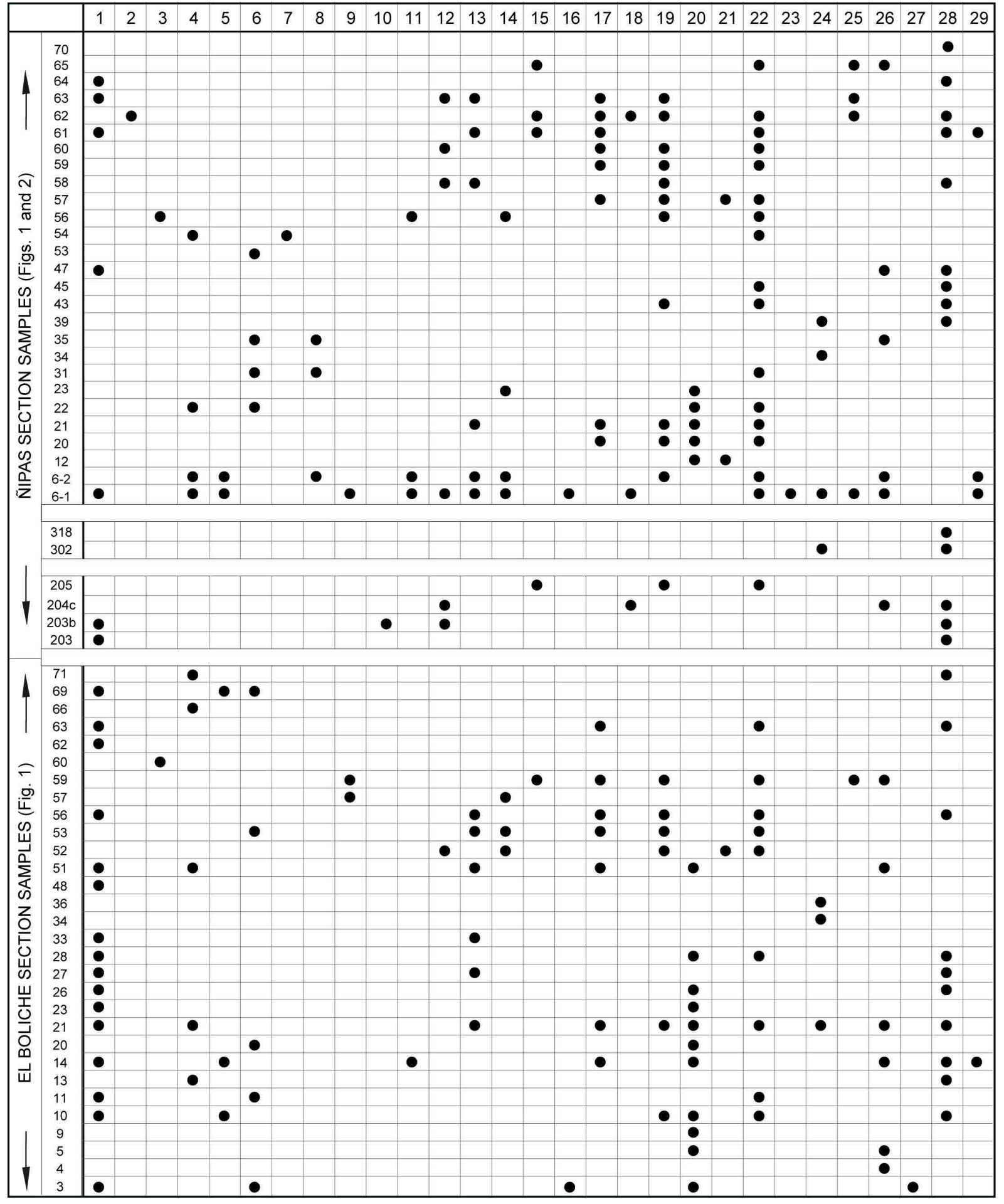

1. Alveolar-septal structure 2. Blocky Calcites

3. Brecciated and nodular textures

4. Burrowed

5. Discontinuous carbonate crusts

6. Cavities

7. Cavities filed by microspar

8. Cavities with spar infillings

9. Cavities with calcite crystal growths

10. Channel porosity due to rootlets
11. Circumgranular and horitzontal joins planes 12. Circumgranular cracks

13. Coated grains

14. Cracking and incipient brecciation

15. Crystal silt vadose infillings

16. Cyanobacteria remains

17. Granular limestones due to granification

18. Incipient nodulization

19. Intraclasts

20. Nodular masses of clotted microbial micrite and microbial filaments
21. Nodular textures

22. Peloids, some of fecal origin 23. Pendant gravitational cements 24. Plant remains

25. Pseudomicrokarst

26. Rhizoliths

27. Ribbon cement

28. Root casts

29. Scarce asymmetrical shaped pisoids 
Another root-related feature is the alveolar texture, named alveolar-septal structure (Wright, 1986) as well, which is also very common in the San Ignacio Formation carbonates. Generally, it is a less or more complex network of tiny adjacent pores or voids sharing the same micrite wall and defining pores of variable shapes (irregular, elongated and rounded); these pores are filled with sparry calcite (Fig. 3F, G). The alveolar texture is widely associated to root traces, adjacent to them or filling them. Numerous examples of similar alveolar fabrics have been described by Goldstein (1988), James and Choquette (1990), Bain and Foos (1993), Alonso-Zarza (2003) and Marty and Meyer (2006). In some cases, other examples of alveolar septal structures occur, showing a rim of cement around the cavity where alveolar texture is developed and with crystals of calcite increasing in size towards the centre of the pores (Fig. 3H). This type is rather similar to that described in the Eocene palustrine limestones of the Isle of Wight (SE England) by Armenteros (2010).

Concerning stumps-related features, Césari et al. (2012) identified in the silicified trunks the presence of tunnel-like structures. Most of the galleries intersect each other to form a cross-like structure (Fig. 4A). Galleries (Fig. 4A, B) enclose ovoid to spherical fecal pellets or coprolites to come from arthropods (oribatid mites); the coprolites contain many tiny fragments of plant tissues (Fig. 4B, C). Some fecal pellets also occur within the parenchymatous tissue of roots and rootlets. Presence of xylophagy is represented in the wood by gallery feeders within the xylem. This plant-arthropod interaction is displayed in the decayed wood of stumps that functioned as nurse logs and within the rootlets of the seedlings that invaded the tissues (Césari et al., 2010). These arthropods had access to the tissues during aerial and subaerial periods.

\subsubsection{Coated grains}

Coated grains consist of rounded to irregular carbonate intraclasts and peloids, or peloidal aggregates occurring in peloidal-intraclastic wackestones to grainstones with abundant cavities. These grains are coated by a single thin layer of dark clotted micrite, sometimes wavy and irregular in thickness; others show thicker envelopes and distinct generations of coating, with several layers of dark microbial micrite, light microspar, clotted micrite, calcite and affected by a subsequent silicification processes (Fig. 4D, E).
Locally, coated grains can be possibly constituted by cyanobacteria remains with irregular micritic coatings (Fig. 4D). This feature is widely described in the palustrine facies literature by Armenteros and Daley (1998), Alonso-Zarza (2003), Marty and Meyer (2006), Alonso-Zarza and Wright (2010a, b, amongst others and references therein) and also in Uruguay and Argentine by Tófalo and Pazos (2010) and Alonso-Zarza et al. (2011).

\subsubsection{Pisoids}

Some incipient pisoids, not very well-developed, are observed together with pseudomicrokarst features and alveolar texture in peloidal-intraclastic limestones. The local occurrence of a special type of pisoids of meteoric diagenesis and probable vadose-phreatic origin following Flügel (2004) is emphasized (Fig. 4F). These pisoids show asymmetrical shape consisting of coated carbonate grain and characterized by concentric and irregular layers formed by calcite crust-like around a dark micritic non-skeletal nucleus. These particular pisoids are associated also with undulating and laminar crusts and circumgranular cracks (see descriptions bellow).

\subsubsection{Pseudomicrokarst}

Irregular and complex cavities with typical characteristics of pseudomicrokarst processes (Plaziat and Freytet, 1978) occur; furthermore, secondary porosity was enhanced by this type of process. These pedogenic features with planar and circumgranular cracks and irregular cavities are quite abundant; the cavities are filled with vadose silt, blocky calcite and reworked intraclasts and/or peloids of the same nature as the enclosing matrix (Fig. 4G, H). These structures are generally developed in peloidal-intraclastic grainstones to wackestone limestones. The examples herein observed are comparable with those described by numerous authors (Alonso-Zarza et al., 1992; Freytet and Verrecchia, 2002; Alonso-Zarza, 2003; Marty and Meyer, 2006; Alonso-Zarza and Wright, 2010a, amongst others).

\subsubsection{Cracking, brecciated and nodular fabrics}

All these features are inter-related and commonly associated with pseudomicrokarst processes as indicated by Dunagan and Turner (2004).

Apart from mudcracks, not very commonly seen on bedding planes, desiccation cracks with different morphologies are common; they mainly consist 

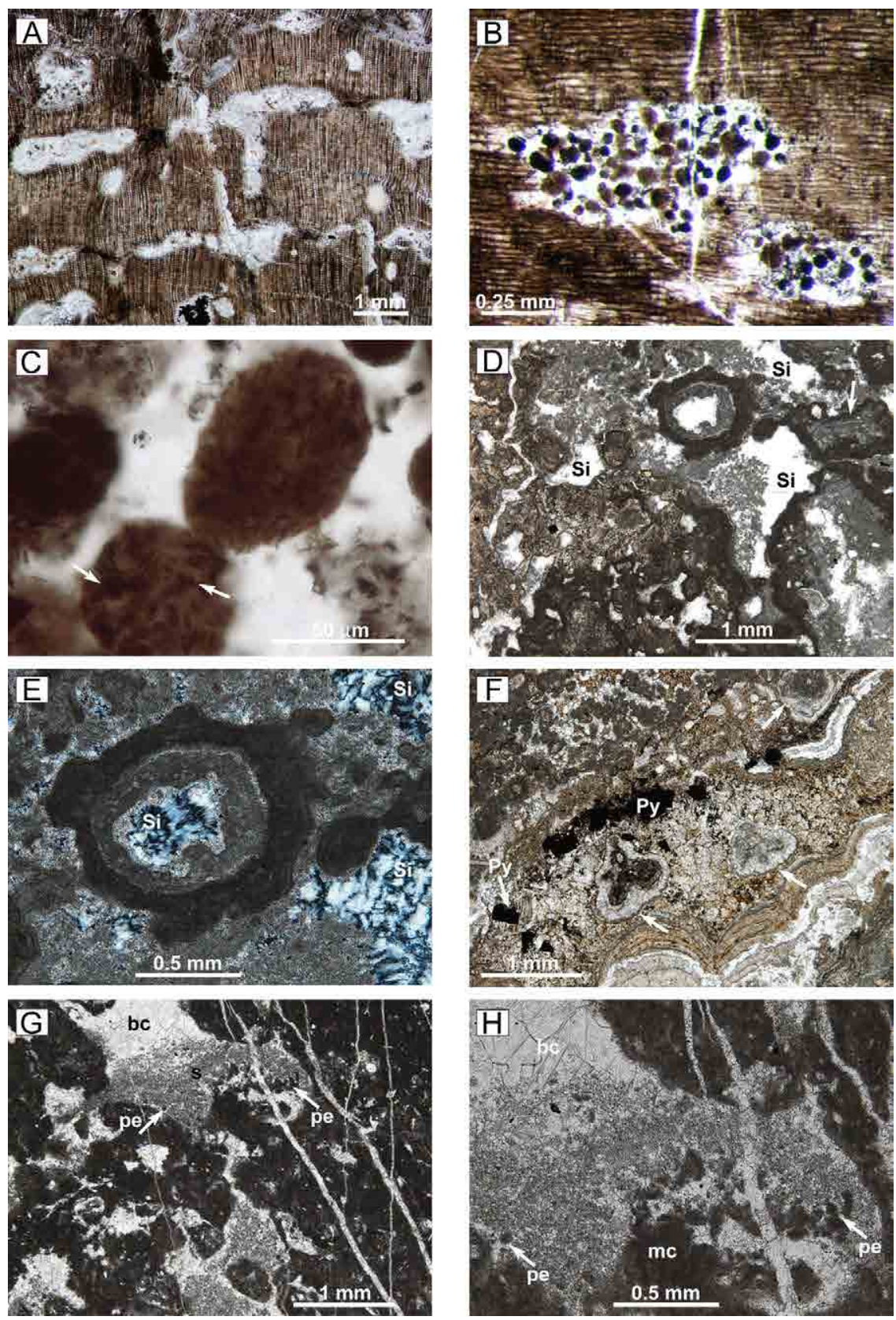

FIG. 4. A. Transverse section of fossilized wood with galleries which intersect each other to form a cross-like structure (taken from Busquets et al., 2013a). B. Longitudinal section of a gallery containing coprolites in radial oblique section of secondary xylem. C. Detail showing the shape of coprolites. Note the heterogeneous tissue fragments in the coprolite (white arrows). D. Carbonate grains surrounded by several laminae of micritic envelopes and fenestral cavities with sediment infillings (Si???) are shown. The white arrow points to probable coated cyanobacteria remains. E. A detail of the previous coated grains, with several layers of dark microbial micrite, light microspar and subsequent silicification processes; fibrous silica replacement (Si) is observed. F. Non-spheroidal shaped pisoids with a micritic nucleus and a rim of carbonate crusts. Undulating laminar crusts and abundant crystals of pyrite (Py) are also seen. G. Pseudomicrokarst features with irregular cavities filled with vadose silt (s), blocky calcite (bc) and reworked peloids (pe) and intraclasts derived from the enclosing matrix. H. Detail of the previous pseudomicrokarst showing irregular cavity filled with internal micritic sediment (mc), peloids (pe; on the lower right corner) and blocky calcite (bc). A-D and F-H photomicrographs in plane-polarized light, and C in crossed polars. 
of horizontal joint planes (Fig. 5A), vertical and circumgranular or curved cracks. Circumgranular cracking is the most abundant and well-developed type with the fissures generally filled with sparry calcite cement (Fig. 5B-F). This type of feature is specially developed in limestones with nodular fabrics or peloidal-intraclastic textures. Many examples of cracks comparable to those of the San Ignacio Formation are well illustrated in the literature on palustrine and pedogenically altered carbonates (Freytet and Plaziat, 1982; Freytet and Verrecchia, 2002; Alonso-Zarza, 2003; Marty and Meyer, 2006, amongst others).

An early brecciation and nodular textures can also be observed on a microscopic scale in the micritic groundmass. In some cases the micritic material is fractured, and the irregularly shaped intraclasts seem to be pieced together as if they have not been transported (Fig. 5D); similar characteristics were described by different authors (e.g., Marty and Meyer, 2006, among many others). Examples of gradation from cracked to less or more developed nodular textures occur. There is a variation from incipient nodulization (Fig. 5E) to more differentiated nodular elements where nodules vary from more or less round to angular (Fig. 5F). In some cases gradational textures passing from a dense to a more open texture can be observed in the same thin section (Fig. 5G). Quite similar features to the above mentioned were reported by Armenteros et al. (1997), Armenteros and Daley (1998), Alonso-Zarza (2003), and Marty and Meyer 2006, amongst others.

\subsubsection{Grainification}

Peloidal and intraclastic grainstones due to diagenetic origin (termed also "granular limestones") have been identified in the San Ignacio Formation carbonates (Busquets et al., 2013b); locally they grade to packstones, wackestones and mudstones with fenestral fabric (Fig. 5H) and they consist of poorly sorted peloids and intraclasts, round to irregular in shape. These facies are related to pedogenically modified limestones and are of diagenetic origin as a result of "grainification" (Freytet and Plaziat, 1982; Mazzullo and Birdwell, 1989; Wright, 1990). According to Alonso-Zarza (2003) the "granular limestones" are the more developed palustrine facies.

\subsubsection{Cements}

Several types of carbonate cements stand out, namely carbonate crusts, ribbon spar, crystal silt infillings, spar crystals with pendant morphologies and secondary carbonate growths with different habits covering pore and cavity walls.

Discontinuous carbonate crusts are meteorically formed carbonate cement infilling voids or adapting to the substrate with several generations of in situ carbonate layers. They are sparsely distributed, show scarce lateral extension and appear mainly in peloidal-intraclastic wackestones to grainstones with abundant cavities. The most common are undulating laminar crusts formed by carbonate laminae alternating in color, dark and light grey and brownish, and in nature, micrite and thicker fibrous layers (Fig. 6A). Examples of different types of cement crusts are given by Esteban and Klappa (1983), Arp (1995), and Flügel (2004).

Ribbon spar cements occur filling voids and are associated to carbonates with fenestral fabrics, peloidal and alveolar textures. The ribbon spar appears as a thin coating or several layers that are, locally, incomplete (Fig. 6B). These cements are comparable to those described by Goldstein (1988) in late Carboniferous paleosoils.

Crystal silt (vadose) infillings are found in irregular cavities occurring mainly in peloidal, intraclastic wackestones to packstones with a complex of features such as abundant porosity, in part pseudomicrokarst cavities, coated grains, pedogenic crusts, shrinkage cracks, and alveolar texture. Not very commonly, spar cement showing pendant gravitational morphologies are present at the top of cavities (Fig. 6C).

Apart from the above-mentioned features, evidence of micro-dissolution processes is patent by means of scanning electron microscope. Cavities are usually filled with silica cement but in fewer cases acicular inorganic carbonate microcrystals growing perpendicular to cavity walls also can be seen (Fig. 6D, E). These microcrystals have different sizes and can exceed $20 \mu \mathrm{m}$ in length (Fig. 6E).

\subsubsection{Other biogenic microcomponents}

Observation through scanning electron microscope also has revealed the presence of a variety of biogenic constituents of microbial origin in most of the pedogenic studied samples. They are one of the most important components observed in the groundmass, alveolar-septal structure, micritic coatings and cavities and exhibit significant differences in size and shape.

Individual smooth and rod-like carbonate microcrystals of different sizes and morphologies 

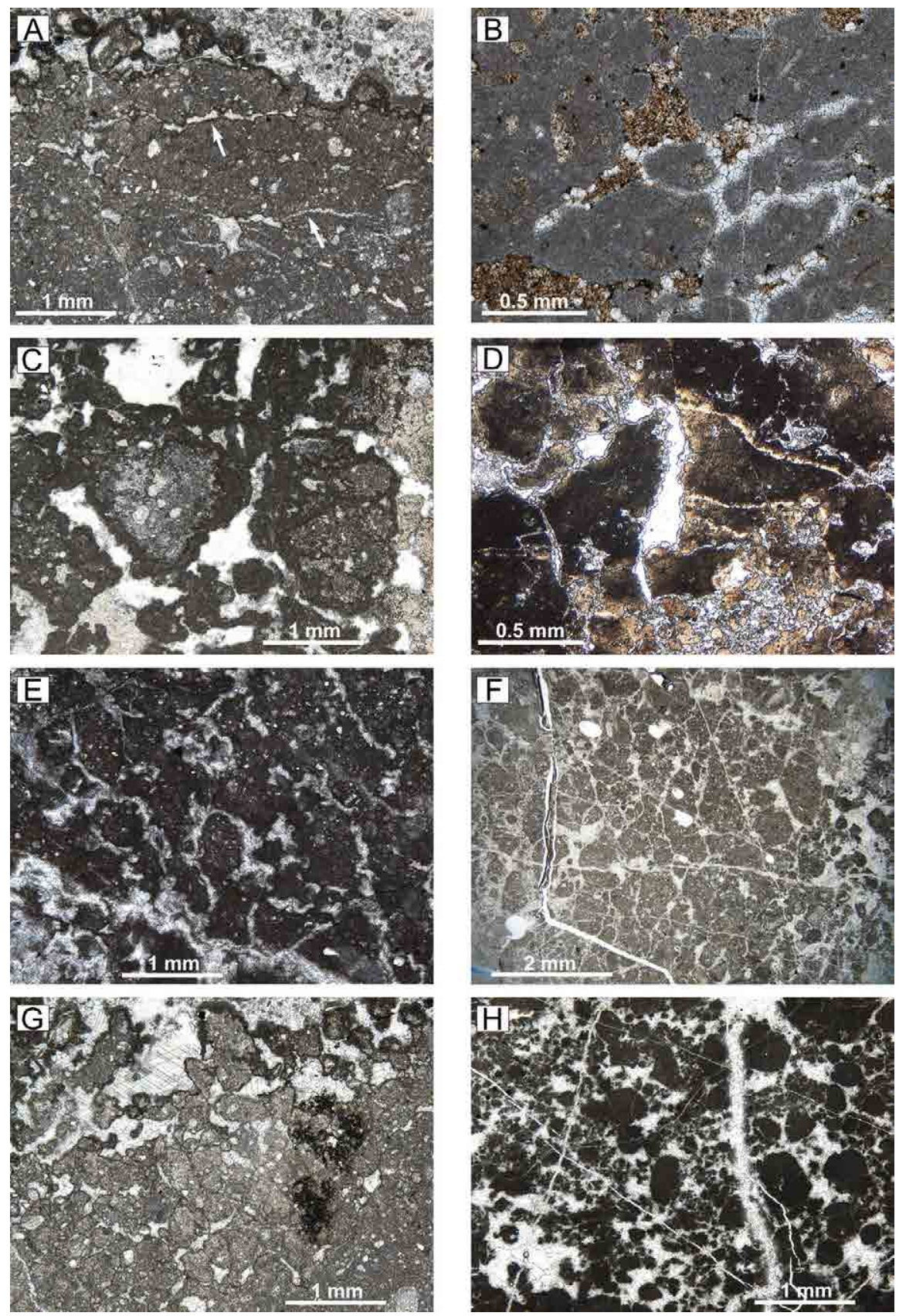

FIG. 5. A. Horizontal planar fractures (white arrows), infilled by sparite in an incipient nodular limestone. B. A detail of a complete and incipient circumgranular cracking in carbonate muds. Some planar cracks are also shown. C. A view of peloidal and intraclastic packstone-wackestone showing circumgranular cracking and irregular micritic coatings around intraclasts. D. Cracked and partly brecciated limestone (in part silicified) and incipient development of nodules. Note planar and circumgranular cracks infilled with spar calcite, and micritic clasts with sparite cements. E. Incipient nodular fabric showing irregular to circumgranular dessication cracks. F. Irregular well-developed nodular structure from curved and planar fissures. Intraclasts, peloids fracturing and brecciation are also shown. G. Transition from micritic dense microstructure (on the right side) to another texture with differentiated nodular elements (on the left) and curved cracks. Some irregular coated grains and spar cement infilling voids are seen at the top of the photomicrograph. H. Petrographic aspect of syngenetic grainstones (granular limestones). A-H photomicrographs in plane-polarized light. 

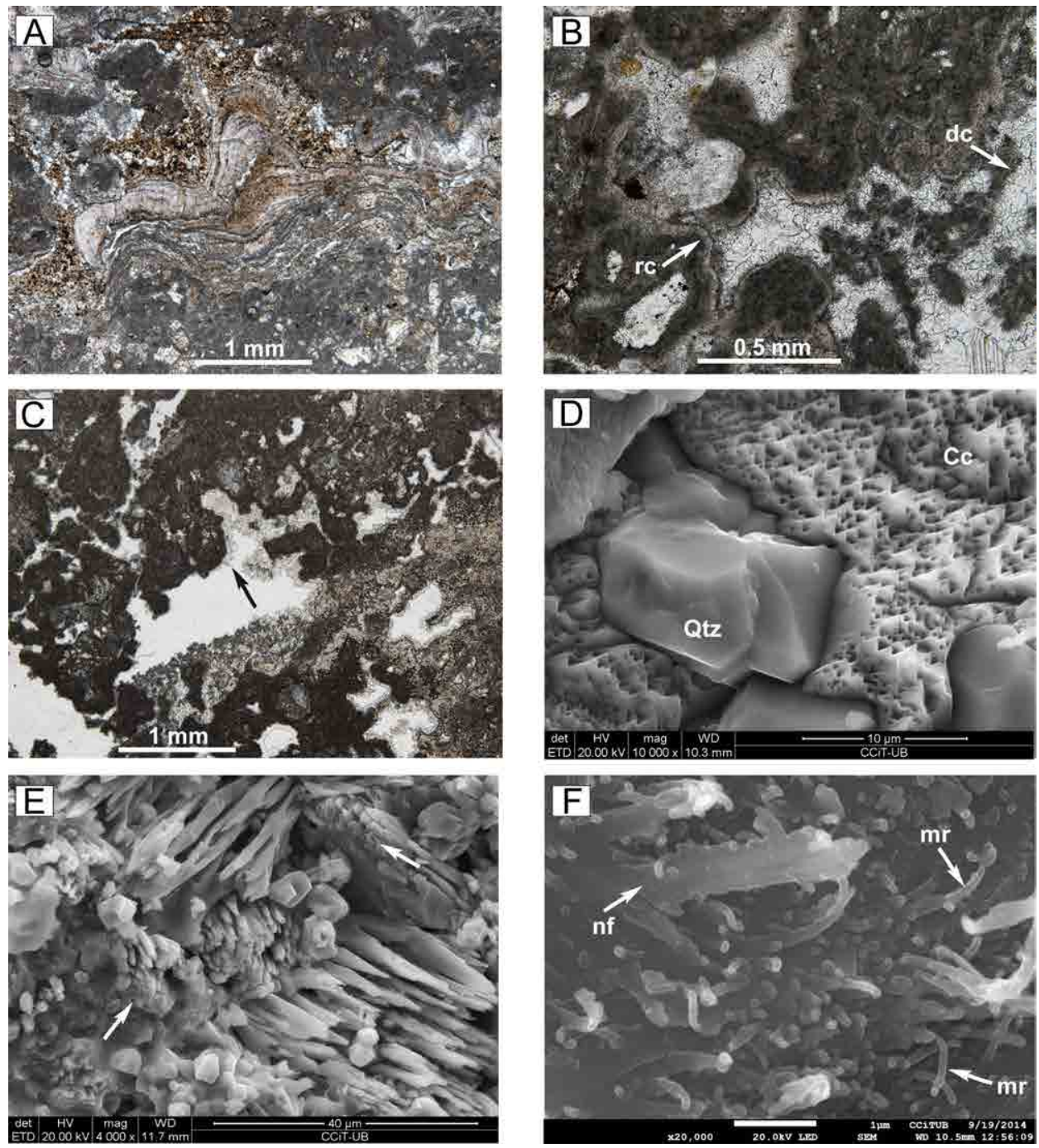

FIG. 6. A. Laminar and undulated crusts formed by fibrous calcitic and micritic layers of variable thickness and color. B. Layers of vertically oriented ribbon spar (rc) underlain by drusy calcite (dc) or surrounding micrite sediment are shown. C. Irregular cavity filled at the bottom by crystalline silt (vadose) carbonates with subsequent growth of crystals. In the roof (see arrow) spar crystals with pendant, gravitational morphologies are observed. D. SEM image of partially dissolved carbonates and silica cement (Qtz) filling voids. E. SEM image of acicular inorganic carbonate microcrystals ( $\geq 20 \mu \mathrm{m}$ long) rooted in partially dissolved carbonate (arrows) cavity. F. SEM image of micro-rods (mr) with curved shape and bulbous terminations ( $<2 \mu \mathrm{m}$ long), and nano-fibres (nf) with straight shape and planar terminations ( $\geq 4 \mu \mathrm{m}$ long). A-C photomicrographs in plane-polarized light.

have been identified. In many cases they are acicular crystals smaller than $2 \mu \mathrm{m}$ long (Fig. 6F) comparable to micro-rods in the sense of Verrecchia and Verrecchia (1994), Loisy et al. (1999) and Zhou and Chafetz (2009). In other cases rod-like carbonate microcrystals have lengths greater than $2 \mu \mathrm{m}$ (Fig. $6 \mathrm{~F}$ ) and may exceed $12 \mu \mathrm{m}$ (Fig. 7A); these microcrystals can be comparable to the nano-fibres described by
Alonso-Zarza (2018). Micro-rods and nano-fibres can show straight or curved shape with planar or bulbous terminations as those shown by Loisy et al. (1999) and Zhou and Chafetz (2009) (Figs. 6F, 7A). Other abundant calcified micro-components have short rod-shaped morphology and less than $2 \mu \mathrm{m}$ in length. They are bacilliform bacteria that can occur as individual cells (bacillus), in pairs 

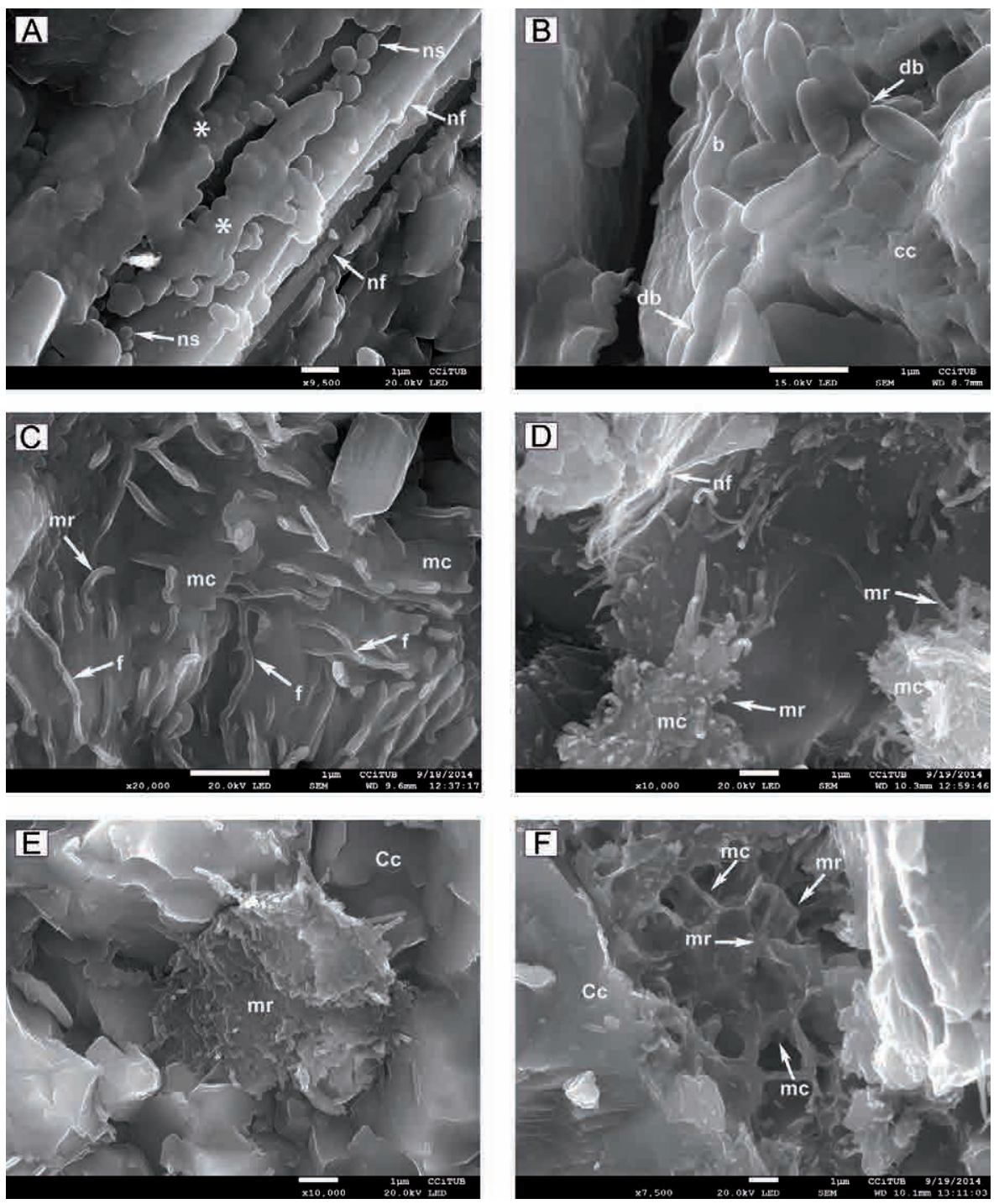

FIG. 7. SEM images. A. Partial view of nano-fibres (nf) with straight shape and $>12 \mu \mathrm{m}$ long. Note the abundance of associated nanospheres (ns) with diameters $<1 \mu \mathrm{m}$, probably coccoid-type bacteria, which appear as individual crystals or aggregates that can coalesce (stars). B. Calcified bacillus-type bacteria (b) of $<1.5 \mu \mathrm{m}$ long and diplobacillus-type bacteria (dp) over partially dissolved carbonates (cc). C. Micro-rods (mr) and calcified filamentous-type bacteria (f) giving rise to pedogenic micritic platelets $(\mathrm{mc})$. D. Formation of pedogenic micrite $(\mathrm{mc})$ from micro-rods $(\mathrm{mr})$ and nano-fibres $(\mathrm{nf})$ aggregates. E. Cluster formed by micro-rods (mr), that have partially lost their individuality, within carbonate voids $(\mathrm{Cc})$. F. Formation of pedogenic micrite platelets $(\mathrm{mc})$ from coalescence of micro-rods $(\mathrm{mr})$, rooted in carbonate voids $(\mathrm{Cc})$.

joined end-to-end (diplobacillus) or forming chains (streptobacillus) (Fig. 7B). Furthermore, calcified micro-organisms with branching pattern have been found and could be interpreted as filamentous bacteria similar to some of those described by Zhou and Chafetz (2009) (Fig. 7C). Finally, spherical to sub-spherical calcified micro-organisms with $<1 \mu \mathrm{m}$ in diameter appear isolated or forming aggregates and commonly associated to nano-fibres (Fig. 7A). They are nano-spheres and most likely correspond to coccoid-type bacteria (Zhou and Chafetz, 2009).

Micro-rods, frequently coalesce to form clusters in which they can be identifiable or lose their identity and give rise to micritic crystals during diagenetic 
processes (Loisy et al., 1999) (Fig. 7D-F); in our case different stages of these diagenetic processes are also observed related to other components of microbial origin.

\section{Discussion}

The carbonates of the upper part of the San Ignacio Formation exhibit a variety and abundance of typical lacustrine-palustrine features as above described (roots and stumps-related microstructures, alveolar texture, coated grains, pseudomicrokarst with vadose and internal sediment fills, different types of desiccation cracks, brecciation and nodularization, meteoric dissolution and cementation). These microfabrics have many similarities with subaeriallygenerated features described in numerous palustrine, paleosoils, calcretes and peritidal carbonates of different ages (Freytet and Plaziat, 1982; Goldstein, 1988; Alonso-Zarza et al., 1992; Bain and Foos, 1993; Eggleston, 1994; Dickson and Saller, 1995; Armenteros and Daley, 1998; Dunagan and Driese, 1999; Alonso-Zarza, 2003; Dunagan and Turner, 2004; Marty and Meyer, 2006; Zhou and Chafetz, 2009; Armenteros, 2010; Tófalo and Pazos, 2010; Alonso-Zarza and Wright, 2010a; Alonso-Zarza et al., 2011; Alonso-Zarza, 2018).

Concerning the roots and stumps-related microstructures, the alveolar texture is interpreted basically in relation to roots and rootlets penetration and their calcification/diagenetic alteration (Steinen, 1974; Goldstein, 1988; Bain and Foos, 1993), or due to coalesced rhizoliths (Esteban and Klappa, 1983) or caused by fungal activity (Wright and Tucker, 1991; Alonso-Zarza, et al., 1992). However, in the upper part of the San Ignacio Formation, the alveolar texture is widely associated to root traces, adjacent to them or filling them. Furthermore, the special type of the alveolar septal structure before described (Fig. 3H) has been linked to phreatic cement by Armenteros (2010). All these above mentioned microfabrics are related to silica-permineralized tree remains and burrowing plant activity recorded in the fossil forest level and in others where fossil plants remains were preserved. This fossil forest grew under recurrent wetter and drier conditions, which could have derived from oscillating climate that controlled the position of the water table. Indistinct wood growth rings indicate that this ecosystem experienced an overall humid, warm climatic regime (Césari et al.,
2012). The finding of galleries, in the original wood of the silicified trunks, containing coprolites (Fig. 4A-C) interpreted to come from arthropods (oribatid mites) took place during periodic aerial exposition, when the arthropods had access to the tissues. Oribatid mites produce irregular feeding galleries that can become large relative to the size of the mite. At present, they live in the uppermost layer of the soil, leaf litter, or other debris where they are common microherbivores and detritivores (Habgood et al., 2004) of dead, aerially-derived plant tissues at ground level, as well as root-penetrated tissues (Labandeira et al., 1997).

The occurrence of pseudomicrokarst (Fig. 4G, H) is clearly indicative of subaerial exposition. According to Plaziat and Freytet (1978) and Freytet and Plaziat (1982) it is an early pedogenic-diagenetic process caused by root penetration before lithification. In this process desiccation, reworking, dissolution, and biologic activity (roots, micro-organisms and meso-organisms) are involved, presumably in periodically exposed zones (see also Alonso-Zarza et al., 1992; Alonso-Zarza and Wright, 2010a). The pseudomicrokarst cavities are filled of coarse and fine internal sediment (vadose) and varied cements. According to Freytet and Verrecchia (2002) its origin is related to long-rooted vegetation in a mud, recently exposed and this is a step for pedogenesis.

Cracking, brecciation, nodulization and grainification (Fig. 5) fabrics correspond to different stages in the secondary alteration of the original carbonate texture in relation with the extent of exposure and thus, the intensity of pedogenic modification; cracking (horizontal and circumgranular cracks and incipients nodules) could represent the minor pedogenic modification, and the nodular and peloidal-intraclastic "grainstones" (granular limestones) are degrees successively more evolved in the pedogenic process altering the carbonate deposits of the San Ignacio Formation. According to Armenteros et al. (1997), Armenteros and Daley (1998), and Alonso-Zarza (2003), there is a development and evolution of pedogenic structures in palustrine facies, from less to more pedogenically modified limestones induced by desiccation and root activity that in the San Ignacio Formation played a relevant role. The final stage is a progressive "grainification" (Wright, 1990) that took place resulting in the formation of diagenetic grainstones (Wright, 1990; Wright and Tucker, 1991; Alonso-Zarza et al., 1992). The granular limestones, 
and also the pseudomicrokarst, are the most developed palustrine facies; the formation of these syngenetic textures are due to repeated wetting and drying of the lake sediments and related to root vegetation (Alonso-Zarza, 2003 and references therein).

The crystal silt infillings in pseudomicrokarst cavities and the pendant cement (Fig. 6C) are common constituents of the cement in the vadose zone (Freytet and Plaziat, 1982) and the ribbon spar (Fig. 6B) cement is also possibly indicative of vadose origin according to Goldstein (1988). Furthermore, cavities formed by meteoric dissolution processes are filled by silica cement and, in minor cases there is growth of acicular inorganic carbonate crystals rooted in the walls of these cavities (Fig. 6E). Precipitation of inorganic acicular crystals is caused by physicochemical processes that act during long dry spells alternating with brief wet periods in vadose contexts with very high carbonate supersaturation and extreme evaporation (Verrecchia and Verrecchia, 1994). In this case, the scarcity of inorganic acicular carbonate precipitation suggests that there was not a high carbonate supersaturation of the solutions or long dry periods and intense evaporation conditions. The SEM study has revealed the abundance of microcrystals of carbonate such as micro-rods, nano-fibres, filaments and nano-spheres. The origin of micro-rods and nano-fibres has been related to physicochemical processes or to a microbial origin (Verrecchia and Verrecchia, 1994; Loisy et al., 1999, among others). However, in this case all of them are of microbial origin corresponding to different calcified bacilliform (micro-rods, nano-fibres and short rod-shaped morphologies), filamentous and coccoidal bacteria, among others.

The whole structures and microfeatures observed in the limestones of the San Ignacio Formation prove the important role of a well-established vegetation cover and associated micro-organisms, mainly bacteria, in the development of pedogenesis and formation of paleosoils. Vascular rooted vegetation act in two different ways: 1) provoking bioturbation, cracking and enlargement of voids by penetrating the carbonate muds, and/or 2) carbonate accumulation by direct calcification of the root cells or inducing biochemical precipitation of carbonate around the rhizosphere (Alonso-Zarza, 2003; Alonso-Zarza, 2018). Micro-organisms also promote the intracellular and extracellular biomineralization within the rhizosphere, by direct calcification or through their metabolic activity, inducing the secondary precipitation of micrite and the induration of soil (Loisy et al., 1999; Zhou and Chafetz, 2009; among others).

The features of the palustrine carbonates in the upper part of the San Ignacio Formation can also occur in pedogenic and calcrete deposits (Platt and Wright, 1992; Armenteros and Daley, 1998; Alonso-Zarza and Wright, 2010a, b). An important difference to take into account is their close association with lacustrine sublittoral limestones (Flügel, 2004). The palustrine carbonates here studied are associated with lacustrine subaqueous limestones (microbialites: thrombolites and stromatolites). In some cases, with minor pedogenic modifications, it is possible to identify the original lacustrine mud, mostly of bacterially induced origin; however, in more advanced pedogenic stages, the primary mud texture of the deposits is hardly recognizable. Although a convergence between palustrine and calcrete characteristics can exist, well-developed features of calcretes such as, soil pisoids, laminar crusts, tepee structures, meniscus cement, Microcodium, have not been recorded here. Furthermore, no reddish-brown or pink halos, mottled musdstones, nodular calcretes, massive calcretes or iron oxides have been observed. Thus, the absence of calcretes would reveal short time periods of subaerial exposure (Platt and Wright, 1992; Alonso-Zarza, 2003).

Concerning paleosoils they are developed in subaquatic or subaerial conditions over microbial carbonate and volcanic deposits and are typically of marginal-lacustrine and palustrine systems (Busquets et al., 2013b). One of these paleosoils constitutes the substrate of the well-preserved fossil forest recorded in this formation (Césari et al., 2010, 2012). In general, they are thin and weakly developed corresponding to immature paleosoils. Therefore, the chemical and physical weathering processes and biological activity were not long enough in time to generate mature paleosoils, this would indicate short intervals of subaerial exposure.

The arrangement of the carbonate deposits in repeated shallowing-upward sequences led to successive and extensive subaerial exposure in this succession but during short periods of time, as mentioned above, due to frequent water level oscillations in the lacustrine-palustrine system, and burial related to volcanic supply and tectonic subsidence. It should be noted that the upper part of the studied formation is made of alternating carbonate and 
volcanic deposits. The intermittent volcanic activity greatly affected to this stratigraphical succession, and the accumulation of volcanic ash-fall deposits interrupted repeatedly the carbonate and paleosoils development, and pyroclastic flows (ignimbrites) partially destroyed them. This latter is indicated by the finding of ignimbrites bearing fragments of previously permineralized vascular plants and pedogenic carbonates (pedorelicts) coming from the substrate (Fig. 8A, B) (Busquets et al., 2013b). Moreover, the volcanic rocks show also clear evidences of subaerial exposure and are modified by pedogenesis and meteoric processes; pores due to decayed plant roots filled with calcite cement, and discontinuous undulating laminar crusts structures of carbonate laminae are observed (Fig. 8C, D).

Regarding the prevailing climatic conditions affecting to these deposits, all above mentioned features may suggest an intermediate between semiarid to sub-humid climate as evidenced by rhizoliths, alveolar-septal structure, brecciation, dissecation and pedogenic cracks, as well as scarce pseudomicrokarsts and lack of evaporite levels or typical calcretes (Platt and Wright, 1992; Dunagan and Driese, 1999; Dunagan and Turner, 2004). However, the features of the preserved fossil forest that indicate periods of wetting and drying conditions and the abundance of micro-organism, suggest a transition to a more sub-humid climate (Césari et al., 2010, 2012; Zhou and Chafetz, 2009).

\section{Conclusions}

1. The palustrine-lacustrine facies of the upper part of the San Ignacio Formation, made up of alternating microbial carbonates (stromatolites, thrombolites) and volcanic rocks (pyroclastic, epiclastic and lava flows), were subjected to successive subaerial exposure linked to fluctuations in water level. These fluctuations are related to contemporary volcanic supply, tectonic subsidence, dome-shaped microbial carbonate growth or an oscillating climate. Consequently, these deposits were affected
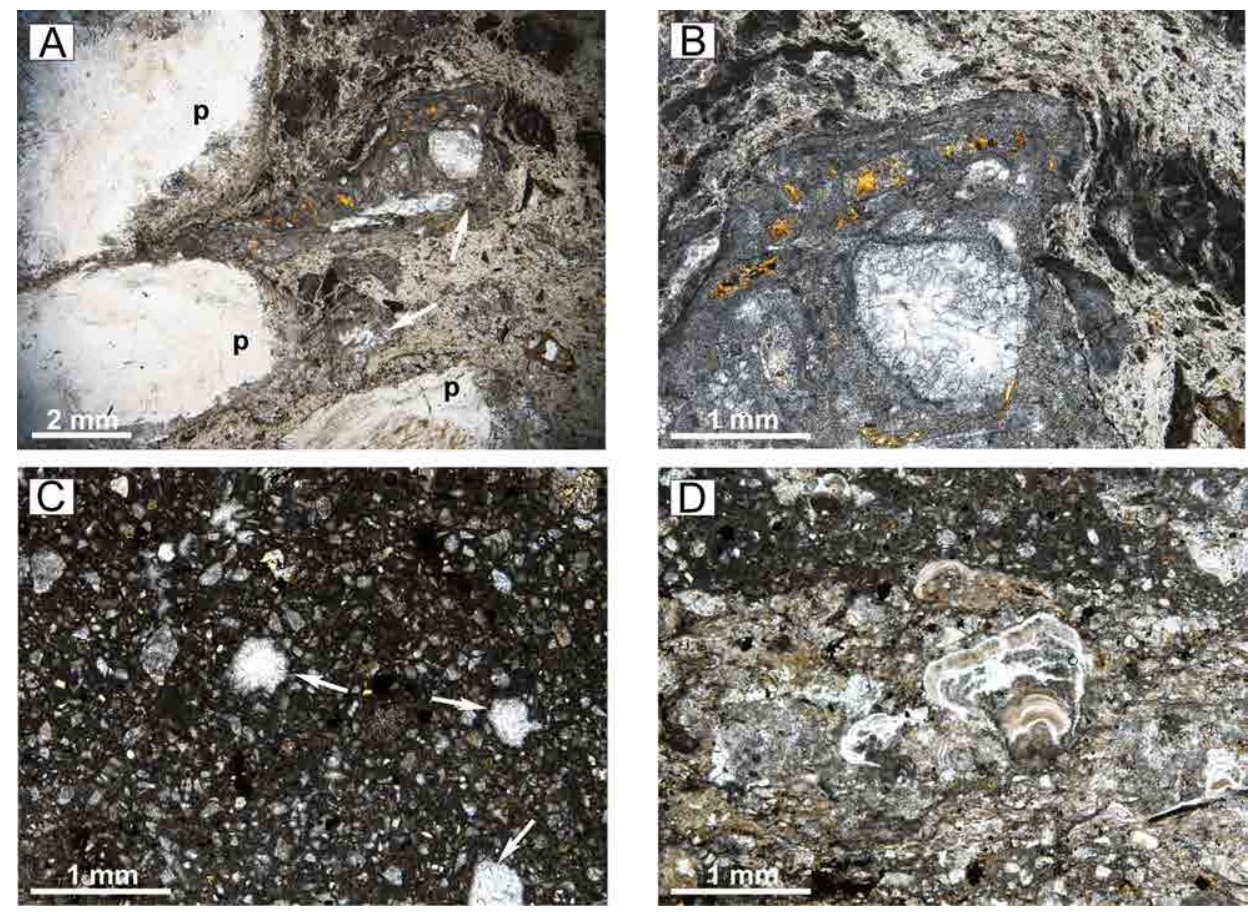

FIG. 8. A. Clasts of silica-permineralized plants (p), and clasts of carbonates previously modified by pedogenic processes (pedorelicts; white arrows), incorporated in a pyroclastic flow (ignimbrite). B. Detail of the previous pedogenic carbonate clast (pedorelicts) inside the ignimbrite and foliation deflected around the clast. C. Cross section of carbonate-filled voids due to decayed plant roots (pedotubule, white arrows) in a volcanic sandstone. D. Undulate crusts formed by carbonate laminae alternating in color adapted to a volcanic sandstone substrate. A-D photomicrographs in plane-polarized light. 
by different degrees of pedogenic, meteoric diagenesis, and erosional processes.

2. Field observations of subaerial exposure are not visible except for a few beds yielding mudcracks, presence of a well-preserved fossil forest with trunks in life position, abundant root structures in several horizons, and bedforms of calcareous clasts caused by turbulent water currents. Thus, criteria to deduce subaerial exposure consist mainly of the analysis of microfabric features.

3. A widespread range of microfabrics reflecting emersion, pedogenesis and associated reworking were identified including root marks and stumps related structures (rhizoliths, alveolar texture and plant-arthropod interaction), pisoids, coated grains, cracking (circumgranular or curved cracks, planar cracks), pseudomicrokarst, brecciation, nodule formation, carbonate crusts, among others. Aerial exposition is evidenced as well by the finding of tunnel-like structures and coprolites belonging to arthropods (oribatid mites) in the silicified trunks.

4. Evidences of meteoric dissolution and cementation (phreatic and vadose) are well recorded by the occurrence of a special type of alveolar-septal structure, pseudomicrokarst cavities with vadose silt infillings, pendant gravitational and ribbon spar cements, incipient and asymmetrically shaped pisoids, and discontinuous carbonate crusts.

5. The microfabrics identified represent different stages of pedogenic evolution of these deposits and the original lacustrine mud only can be recognizable in the cases were pedogenic modification is minor. The less evolved step is characterized by cracking and incipient nodulization giving way successively to a nodular fabric and peloidal-intraclastic "grainstones" (or granular limestones); the final and more evolved stage is the formation of diagenetic grainstones.

6. The lack of calcretes and the immature character, in general, of paleosoils point out to short intervals of subaerial exposure due to frequent water level oscillations in the lacustrine-palustrine system, intermittent volcanic supply, fluctuating climatic conditions and tectonic subsidence.

7. The rooted vegetation with the development of a fossil forest as well as the abundance and variety of micro-organisms mainly of bacterial origin (micro-rods, short rod-shaped morphologies, nano-fibres, filaments and nano-spheres) played an important role in the pedogenic and subaerial diagenetic processes affecting these deposits.
8. The prevailing climate could correspond to intermediate between semi-arid to sub-humid conditions as evidenced by the macro and microstructures studied, lack of evaporite levels or typical calcretes. The alternating wetting and drying conditions in which the fossil forest developed and the abundance and diversity of micro-organisms, suggest a transition to a more sub-humid climate conditions.

\section{Acknowledgements}

We acknowledge reviewers M.S. Raigemborn and R. Tofalo, and editor W. Vivallo, for their constructive comments and corrections, which resulted in the significant improvement of this article. This work has been supported by CGL2009-13706-CO3 (PALEOANDES II) and CGL201238396-C03 (TORANDES) projects of the Spanish Program for Science Technology (I+D+I) and FEDER Funds of the EU, and partially funded by Generalitat de Catalunya (Grup de Qualitat 2014-SGR-467). Thanks are due to Centres Científics i Tecnològics (CCiTUB), Universitat de Barcelona, for technical support. The figures are enhanced by the help of $\mathrm{D}$. Amblàs.

\section{References}

Alonso-Zarza, A.M. 2003. Paleoenvironmental significance of palustrine carbonates and calcretes in the geological record. Earth-Sciences Reviews 60: 261-298.

Alonso-Zarza, A.M. 2018. Study of a modern calcrete forming in Guadalajara, Central Spain: An analogue for ancient root calcretes. Sedimentary Geology 373: 180-190.

Alonso-Zarza, A.M.; Wright, V.P. 2010a. Palustrine carbonates. In Carbonates in Continental Settings: Facies, Environments and Processes (Alonso-Zarza, A.M.; Tanner, L.H.; editors). Developments in Sedimentology 61: 103-131.

Alonso-Zarza, A.M.; Wright, V.P. 2010b. Calcretes. In Carbonates in Continental Settings: Facies, Environments and Processes (Alonso-Zarza, A.M.; Tanner, L.H.; editors). Developments in Sedimentology 61:225-267.

Alonso Zarza, A.M.; Calvo, J.P.; García del Cura, M.A. 1992. Palustrine sedimentation and associated featuresgrainification and pseudo-microkarst-in the Middle Miocene (Intermediate Unit) of the Madrid Basin, Spain. Sedimentary Geology 76: 43-61.

Alonso-Zarza, A.M.; Genise, J.F.; Verde, M. 2011. Sedimentology, diagenesis and ichnology of Cretaceous and Paleogene calcretes and palustrine carbonates from Uruguay. Sedimentary Geology 236: 45-61. 
Armenteros, I. 2010. Diagenesis of carbonates in Continental settings. In Carbonates in Continental Settings: Geochemistry, Diagenesis and Applications (Alonso-Zarza, A.M.; Tanner, L.H.; editors). Developments in Sedimentology 62: 62-151.

Armenteros, I.; Daley, B. 1998. Pedogenic modification and structure evolution in palustrine facies as exemplified by the Bembridge Limestone (Late Eocene) of the Isle of Wight, southern England. Sedimentary Geology 119: 275-295.

Armenteros, I.; Daley, B.; García, E. 1997. Lacustrine and palustrine facies in the Bembridge Limestone (late Eocene, Hampshire Basin) of the Isle of Wight, southern England. Paleogeography, Paleoclimatology, Paleoecology 128: 111-132.

Arp, G. 1995. Lacustrine Bioherms, Spring Mounds, and Marginal carbonates of the Ries-Impact-Crater (Miocene, Southern Germany). Facies 33: 35-90.

Bain, R.J.; Foos, A.M. 1993. Carbonate microfabrics related to subaerial exposure and paleosol formation. In Carbonate Microfabrics: Frontiers in Sedimentology (Rezak, R.; Lavoie, D.L.; editors). Springer-Verlag: 17-27.

Burne, R.V.; Moore, L.S. 1987. Microbiolithes: organosedimentary deposits of the benthic microbial communities. Palaios 2: 241-254.

Busquets, P.; Colombo, F.; Heredia, N.; Solé de Porta, N.; Fernández, L.R.; Álvarez Marrón, J. 2005. Age and tectonostratigraphic significance of the Upper Carboniferous series in the basement of the Andean Frontal Cordillera: geodynamic implications. Tectonophysics 399: 181-194.

Busquets, P.; Méndez-Bedia, I.; Colombo, F.; Césari, S.; Cardó, R.; Limarino, O.; Gallastegui, G.; Heredia, N. 2007a. Fossil tree stumps in the Upper Paleozoic of the Sierra de Castaño (Cordillera Frontal, Argentina): paleoenvironmental importance. Instituto Geológico y Minero de España, Cuadernos del Museo Geominero 8: 63-67. Madrid.

Busquets, P.; Méndez-Bedia, I.; Gallastegui, G.; Colombo, F.; Heredia, N.; Cardó, R.; Limarino, O. 2007 b. Late Paleozoic microbial lacustrine carbonate and related volcanic facies from the Andean Frontal Cordillera (San Juan, Argentina). Cuadernos del Museo Geominero, Instituto Geológico y Minero de España 8: 69-74. Madrid.

Busquets, P.; Colombo, F.; Heredia, N.; Cardó, R. 2008. Gravitational sliding in a foreland basin. Late Paleozoic, Cordillera Frontal, Andes, San Juan-Argentina. GeoTemas 10: 466-466.

Busquets, P.; Limarino, C.O.; Cardó, R.; MéndezBedia, I.; Gallastegui, G.; Colombo, F.; Heredia, N.;
Césari, S.N. 2013a. El neopaleozoico de la Sierra de Castaño (Cordillera Frontal andina, San Juan, Argentina); Reconstrucción tectónica y paleoambiental. Andean Geology 40 (1): 172-195. doi: 10.5027/ andgeoV40n1-a08.

Busquets, P.; Méndez-Bedia, I.; Gallastegui, G.; Colombo, F.; Cardó, R.; Limarino, C.O.; Heredia, N.; Césari, S.N. 2013b. The relationship between carbonate facies, volcanic rocks and plant remains in a late Paleozoic lacustrine system (San Ignacio Fm, Frontal Cordillera, San Juan province, Argentina). International Journal of Earth Sciences 102 (5): 1271-1287.

Césari, S.N.; Busquets, P.; Colombo Piñol, F.; Méndez Bedia, I.; Limarino, C.O. 2010. Nurse logs: An ecological strategy in a late Paleozoic forest from the southern Andean region. Geology 38 (4): 295-298.

Césari, S.N.; Busquets, P.; Méndez Bedia, I.; Colombo, F., Limarino, C.O.; Cardó, R.; Gallastegui, G. 2012. A late Paleozoic fossil forest from the southern Andes, Argentina. Paleogeography, Paleoclimatology, Paleoecology 333-334: 131-147.

Dickson, J.A.; Saller, A.H. 1995. Identification of subaerial exposure surfaces and porosity observation in Pennsylvanian and lower Permian shelf limestones, Eastern Central basin Platform, Texas. In Unconformities and porosity in carbonate Strata (Budd, D.A.; Saller, A.H.; Harris, P.M.; editors). American Association of Petroleum Geologists 63: 239-257.

Dunagan, S.P.; Driese, S.G. 1999. Control of terrestrial stabilization on Late Devonian palustrine carbonate deposition: Catskill magnafacies, New York, U.S.A. Journal of Sedimentary Research 69 (3): 772-783.

Dunagan, S.P.; Turner, C.E. 2004. Regional paleohydrologic and climatic settings of wetland/lacustrine depositional systems in the Morrison Formation (Upper Jurassic), Western Interior, USA. Sedimentary Geology 167: 269-296.

Eggleston, J.R. 1994. The facies and depositional environment of an upper Pennsylvanian limestone, Northern Appalachian Basin. In Lacustrine Reservoirs and Depositional Systems (Lomando, A.J.; Schreiber, B.C.; Harris, P.M.; editors). Society of Economic Paleontologists and Mineralogists, Core Workshop 19: 97-319.

Esteban, M.; Klappa, C.F. 1983. Subaerial exposure environment. In Carbonate depositional environments (Scholle, P.A.; Bebout, D.G.; Moore, C.H.; editors). American Association of Petroleum Geologists, Memoir 33: 1-54.

Flügel, E. 2004. Microfacies of carbonate rocks. Springer-Verlag: 976 p. NewYork. 
Freytet, P.; Plaziat, J.C. 1982. Continental carbonate sedimentation and pedogenesis-Late Cretaceous and Early Tertiary of Southern France. In Contributions to Sedimentology (Purser, B.H.; editor). Schweizerbart'sche Verlag 12: $213 \mathrm{p}$.

Freytet, P.; Verrecchia, E.P. 2002. Lacustrine and palustrine carbonate petrography: an overview. Journal of Paleolimnology 27: 221-237.

Goldstein, R.H. 1988. Paleosols of Late Pennsylvanian cycle strata, New Mexico. Sedimentology 35: 777-803.

Groeber, P. 1938. Mineralogía y Geología. Espasa-Calpe Argentina: $492 \mathrm{p}$.

Habgood, K.S.; Hass, H.; Kerp, H. 2004. Evidence for an early terrestrial food web: coprolites from the Early Devonian Rhynie chert. Transactions of the Royal Society of Edinburgh, Earth Sciences 94: 371-389.

Heredia, N.; Rodríguez Fernández, L.R.; Gallastegui, G.; Busquets, P.; Colombo, F. 2002. Geological setting of the Argentine Frontal Cordillera in the flat-slab segment $\left(30^{\circ} 00^{\prime}\right.$ to $31^{\circ} 30^{\prime} \mathrm{S}$ latitude). In Flat Subduction in the Andes (Ramos, V.; McNulty, B.; editors). Journal South American Earth Sciences 15 (13): 79-99.

James, N.P.; Choquette, P.W. 1990. Limestones-The Meteoric Diagenetic Environment 35-73. In Diagenesis (Mcllraeth, I.A.; Morrow, D.W.; editors). Geoscience Canada reprint $4: 35-73$.

Labandeira, C.C.; Phillips, T.L.; Norton, R.A. 1997. Oribatid mites and the decomposition of plant tissues in Paleozoic coal-swamp forests. Palaios 12: 319-353.

Llambías, E.J. 1999. Las rocas ígneas gondwánicas. El magmatismo gondwánico durante el Paleozoico Superior-Triásico. Geología Argentina. Servicio Geológico Minero Argentino, Instituto de Geología y Recursos Minerales, Anales 29: 349-363.

Loisy, C.; Verrecchia, E.P.; Dufour, P. 1999. Microbial origin for pedogenic micrite associated with a carbonate paleosol (Champagne, France). Sedimentary Geology 126: 193-204.

Marty, D.; Meyer, C.A. 2006. Depositional conditions of carbonate-dominated palustrine sedimentation around the K-T boundary (Facies Rognacien, northeastern Pyrenean foreland, southwestern France). In Paleoenvironmental Record and Applications of Calcretes and Palustrine Carbonates (Alonso-Zarza, A.M.; Tanner, L.H.; editors). Geological Society of America 416: 169-187.

Mazzullo, S.J.; Birdwell, B.A. 1989. Syngenetic formation of grainstones and pisolites from fenestral carbonates in peritidal settings. Journal of Sedimentary Petrology 59: 605-611.

Platt, N.H.; Wright, V.P. 1992. Palustrine carbonates at the Florida Everglades: towards an exposure index for fresh-water environment. Journal of Sedimentary Petrology 62 (6): 1058-1071.

Plaziat, J.C.; Freytet, P. 1978. Le pseudo-microkarst pédologique: un aspect particulier des paléo-pedogenéses developpées sur les depôts calcaires lacustres dans le Tertiaire du Languedoc. Comptes Rendues de l'Académie des Sciences 286: 1661-1664. Paris.

Rodríguez-Fernández, L.R.; Heredia, N.; Marín, G.; Quesada, C.; Robador, A.; Ragona, D.; Cardó, R. 1996. Tectonoestratigrafía y estructura de los Andes Argentinos entre $\operatorname{los} 30^{\circ}$ y $31^{\circ}$ de latitud Sur. In Congreso Geológico Argentino, No. 13, Actas 2: 111-124. Buenos Aires.

Rodríguez-Fernández, L.R.; Heredia, N.; García Espina, G.; Cegarra, M.I. 1997. Estratigrafía y estructura de los Andes centrales Argentinos entre los $30^{\circ} 30^{\prime}$ y $31^{\circ} 00^{\prime}$ de latitud Sur. Acta Geológica Hispánica 32 (1-2): 51-76.

Steinen, R.P. 1974. Phreatic and vadose diagenetic modification of Pleistocene limestone; petrographic observations from subsurface of Barbados, West Indies. American Association of Petroleum Geologists, Bulletin 58: 1008-1024.

Tófalo, O.R.; Pazos, P.J. 2010. Paleoclimatic implications (Late Cretaceous-Paleogene) from micromorphology of calcretes, palustrine limestones and silcretes, southern Paraná Basin, Uruguay. Journal of South American Earth Science 29: 665-675.

Verrecchia, E.P.; Verrecchia, K.E. 1994. Needdle-fiber calcite: a critical review and a proposed classification. Journal of Sedimentary Research A64 (3): 650-664.

Wright, V.P. 1986. The role of fungal biomineralization in the formation of early Carboniferous soil fabrics. Sedimentology 33: 831-838.

Wright, V.P. 1990. Syngenetic formation of grainstones and pisolites from fenestral carbonates in peritidal settings: discussion. Journal of Sedimentary Petrology 60: 309-310.

Wright, V.P.; Tucker, M.E. 1991. Calcretes: an introduction. In Calcretes (Wright, V.P.; Tucker, M.E.; editors). International Association of Sedimentologists (IAS) Reprint Series 2: 22 p.

Zhou, J.; Chafetz, H.S. 2009. Biogenic caliches in Texas: The role of organisms and effect of climate. Sedimentary Geology 222: 207-225.

Manuscript received: June 26, 2018; revised/accepted: August 6, 2019; available online: January 31, 2020. 